\title{
PERLINDUNGAN HUKUM PEMBELI DALAM PERJANJIAN JUAL BELI MELALUI SISTEM ELEKTRONIK
}

\author{
Besty Habeahan ${ }^{1}$,Aurelius Rizal Tamba ${ }^{2}$ \\ ${ }^{1}$ Program Studi Ilmu Hukum \\ 2Program Studi Magister Hukum \\ Universitas HKBP Nommensen, Medan-Sumatera Utara-Indonesia \\ e-mail: bestyhabeahan@gmail.com
}

\begin{abstract}
The Research on Buyer Legal Protection in the sale and purchase agreement through an electronic system aims to find out how the validity of the sale agreement through an electronic system and how the form of legal protection of buyers for losses due to damage to goods purchased through an electronic. By the agreement between the seller and the buyer in the sale and purchase agreement, they have the rights and obligations. This research method use Library Research Method and the research carried out in the library, where data is obtained from availeble data by reading, studying books, laws and relations, magazines, scientific paper, legal dictionaries and so on. Based on the method used, the results of this study indicate that the validity of the sale and purchaseagreement through an electronic system still considers the validity of the agreement as Article 1230 KUHP of the Civil Code, namely agreement of both parties, where both parties are capable in doing legal action and cause-effect which is lawfull. Buyer's legal protection for losses due to damage to goods purchased through electronic systems is preventive protection and repressive protection, the buyerwho suffered the loss ca sue for loss or claim the replacement of the damaged goods with goods of the same brand.
\end{abstract}

Keywords: Protection Contract, Electronic System, Legal Protection

\begin{abstract}
Abstrak
Penelitian terhadap Perlindungan Hukum Pembeli Dalam Perjanjian Jual-Beli Melalui Sistem Elektronik bertujuan untuk mengetahui bagaimana keabsahan perjanjian jual-melui sistem elektronik dan bagaimana bentuk perlindungan hukum pembeli atas kerugian akibat rusaknya barang yang dibeli melaluii sistem elektronik. Dengan adanya kesepakatan pihak penjual dan pembeli dalam perjanjian jual-beli maka lahirlah hak dan kewajiban bagi para pihak. Metode penelitian yang digunakan adalah Metode Penelitian Kepustakaan (Library Research) yaitu penelitian yang dilakukan di perpustakaan, dimana data diperoleh dari data yang tersedia dengan cara membaca, mempelajari buku-buku, peraturan perundang-undangan, majalah, karya ilmiah, kamus hukum dan lain sebagainya. Berdasarkan metode yang digunakan, hasil penelitian ini menunjukkan bahwa keabsahan perjanjian jual beli melalui sistem elektronik tetap melihat pada syarat sahnya perjanjian sebagaimana diatur dalam Pasal 1230 KUH Perdata yaitu kesepakatan kedua pihak, kedua belah pihak cakap dalam melakukan perbuatan hukum, objek tertentu dan sebab akibat yang halal. Perlindungan hukum pembeli atas kerugian akibat rusaknya barang yang dibeli melalui sistem elektronik adalah perlindungan preventif dan perlindungan refresif. Pembeli yang menderita kerugian dapat menuntut ganti rugi atau menuntut penggantian barang-barang yang rusak dengan barang yang mereknya sama.

Kata kunci: Perlindungan Perjanjian, Sistem Elektronik, Perlindungan Hukum
\end{abstract}




\section{A. Pendahuluan}

Setiap orang bebas melakukan berbagai hal guna mempertahankan hidupnya, seperti dalam hal ini transaksi jual beli yang terjadi dalam masyarakat dalam rangka memenuhi kebutuhan hidupny. Djoko Prakoso dan Bambang Riyadi juga mengatakan bahwa transaksi jual beli merupakan hak setiap individu/manusia, dikatakan demikian karena jual beli merupakan suatu kegiatan manusia yang diperlukan untuk memenuhi kebutuhan hidupnya sehari-hari. ${ }^{1}$ Dalam suatu transaksi jual beli, apapun jenis benda yang diperjualbelikan mulai dari jual beli biasa seperti jual beli permen di kios-kios sampai jual belil yang dilakukan secara tertulis seperti jual beli tanah, bebas untuk dilakukan dengan syarat tidak melanggar peraturan perundang-undangan yang berlaku.

Jual beli adalah suatu perjanjian timbal balik yang dalam hal ini pihak yang satu (si penjual) berjanji untuk menyerahkan hak milik atas suatu barang, sedangkan pihak yang lainnya (si pembeli) berjanji untuk membayar harga yang terdiri atas sejumlah uang sebagai imbalan dari perolehan hak milik tersebut. ${ }^{2}$

Jual beli sebagaimana diatur dalam buku ke-III Kitab Undang-Undang Hukum Perdata (KUH Perdata) pada Pasal 1457 didefinisikan sebagai berikut: suatu perjanjian dengan mana pihak yang satu mengikatkan dirinya untuk menyerahkan suatu barang, dan pihak yang lain untuk membayar harga yang dijanjikan. Secara spesifik, Pasal 1491 KUH Perdata mengatur tentang kewajibabn penjual terhadap pembelian adalah untuk menjamin dua hal yaitu:

1. Penguasaan barang yang dijual itu secara aman dan tenteram.

2. Tiadanya cacat yang tersembunyi pada barang tersebut atau yang sedemikian rupa sehingga menimbulkan alasan untuk pembatalan.

Perkembangan teknologi saat ini yang begitu pesat dan tidak terhindarkan lagi sangat mempengaruhi gaya hidup dan orientasi masyarakat kearah dunia digital. Masyarakat kini mulai meninggalkan cara-cara konvensional dan menggantikannya dengan cara-cara yang praktis dan efisien, sesuai dengan segi kepraktisan dan kecepatan yang ditawarkan oleh teknologi. Perkembangan teknologi kini telah merambah ke berbagai bidang kehidupan manusia, seperti bidang pendidikan, perdagangan, kesehatan, perbankan, asuransi, hiburan dan berbagai bidang lainnya. Salah satu bentuk perkembangan teknologi adalah komputer dan jaringan internet yang semakin memudahkan masyarakat dalam mengakses berbagai informasi di seluruh dunia. Internet sebagai salah satu perkembangan teknologi yang telah membuka lahan usaha baru, interaksi baru dan jaringan bisnis baru tanpa batas di dunia, internet memudahkan masyarakat untuk berinteraksi bisnis, ekonomi, sosial dan budaya. ${ }^{3}$

Di Indonesia bisnis elektronic commerce telah mengalami kemajuan yang sangat pesat. Ini terbukti tidak sedikit perusahaan yang berbisnis dalam bidang elektronic commerce. Maraknya para pengusaha berinvestasi bisnis dalam bidang elekronic commerce mewajibkan pemerintah untuk lebih waspada akan suatu perubahan di dalam masyarakat. Bisnis elektonic commerce telah didukung oleh peraturannya dan telah dibuat Undang-Undang yang mengaturnya yaitu Undang-Undang No. 19 Tahun 2016 tentang Informasi dan Transaksi Elektronik, namun dalam kenyataan masih banyak para pelaku tidak memahami UndangUndang yang dikeluarkan Pemerintah tersebut sehingga para pihak konsumen dirugikan dalam hal transaksi tersebut.

Perdagangan elektronik yang memperlihatkan bahwa pengguna teknologi informasi menjadisuatu sarana utama untuk menghubungkan antara penjual dan pembeli. Secara

\footnotetext{
${ }^{1}$ Djoko Prakoso dan Bambang Riyadi lany, Dasar Hukum Persetujuan Tertentu di Indonesia, Bina Aksara, Jakarta, 1987, hal. 10.

${ }^{2}$ R. Subekti, Aneka Perjanjian, PT. Alumni, Bandung, 1992, hal. 3.

${ }^{3}$ Ustadiyanto, Riyche, Framwork E-commerce, Andi, Yogyakarta, 2001, hal. 15
} 
elektronik, transaksi yang dilakukan tetap memperdagangkan barang-barang yang pada umumnya menjadi objek perdagangan biasa namun terdapat implikasi tertentu karena karakteristik transaksi jenis ini mencakup hal-hal yang berkaitan dengan adanya informasi, metode pembayaran, yurisdiksi hukum dan kerahasiaan konsumen.

Setiap elektronc commerce haruslah memiliki pembayaran elektronik yang memiliki tingkat perlindungan secara yuridis maupun ekonomis. Oleh sebab itu perlindungan konsumen dalam transaksi elektronc commerce juga dittentukan dan bagaimana pula jaminan dalam transaksi yang terjadi dalam sistem perbankan elektronik yang mencapai jangkauan dunia. ${ }^{4}$ Karena diketahui bahwa transaksi tersebut tidak hanya sekedar menghubungkan kepentingan penjual atau pembeli dalam suatu wilayah tertentu namun berlangsung dari suatu jaringan elektronik dunia yang berasal dari yurisdiksi hukum yang berbeda pula.

Dalam hal melaksanakan jual beli suatu barang, tidak selamanya barang yang dibeli atau yang dijual tersebut adalah barang dalam kondisi baru atau mulus melainkan juga ada barang yang dijual atau dibeli dalam keadaan rusak sehingga dapat menimbulkan kerugian bagi si konsumen. Hal ini pun menimbulkan beberapa permasalahan didalam kegiatan jual-beli barang dalam kondisi rusak tersebut yaitu dengan banyaknya keluhan terhadap kondisi yang tidak seperti apa yang diharapkan dalam barang tersebut, serta banyaknya para pelaku usaha yang menjual barang dalam kondisi bekas ataupun baru yang memberikan toleransi garansi yang sangat singkat seperti memberi garansi hanya selama 1 (satu) bulan saja, sehingga munculnya kebingungan di pihak konsumen pembeli atau istilah lain yang agak dekat dengan konsumen adalah "pembeli".

Penjual tentunya harus menawarkanbarang yang bagus yang apabila dipergunakan oleh si pembeli dalam kondisi baik, sehingga pembeli puas terhadap barang yang dibelinya tersebut. Saat ini memang banyak penjual menawarkan barang yang menurutnya bagus tetapi setelah dipakai oleh si pembeli langsung rusak dan tidak bisa dipakai lagi.

Berdasarkan hal-hal yang dikemukakan dalam latar belakang di atas maka yang menjadi permasalahan dalam penelitian ini adalah:

1. Bagaimanakah keabsahan perjanjian jual beli melalui sistem elektronik?

2. Bagaimana bentuk perlindungan hukum pembeli atas keerugian akibat rusaknya barang yang dibeli melalui sistem elektronik?

\section{B. Metode Penelitian Jenis Penelitian}

Jenis penelitian yang digunakan dalampenelitian ini adalah penelitian yuridis normatif yaitu penelitian hukum yang dilakukan dengan cara meneliti bagian pustaka atau data sekunder. Penelitian hukum normatif disebut juga sebagai peneltiian hukum doktriner karena penelitian ini dilakukan atau ditujukan hanya kepada peraturan-peraturan yang tertulis atau bahan-bahan hukum lainnya. ${ }^{5}$

\section{Metode Pengumpulan Data}

Metode pengumpulan data yang digunakan dalam penelitian ini adalah metode penelitian kepustakaan (library research). Data tersebut diperoleh dari lliteratur, peraturan perundang-undangan, artinya yang sudah baku sehingga data yang ada dilihat dari hukum yang sudah berkekuatan tetap.

\section{Metode Analisis Data}

\footnotetext{
${ }^{4}$ M. Suyanto, Strategi Periklanan Padsa E-Commerce Perusahaan Top Dunia, Andi, Yogyakarta, 2003, hal. 10.

${ }^{5}$ Peter Mahmud Marzuki, Penelitian Hukum, Cetakan keenam, Kencana Prenada Media Grup, Jakarta, 2010, hal. 25.
} 
Metode analisis data yang dipakai adalah metode analisis normatif yuridis. Data tersebut dianalisis menurut hukum dan peraturan perundang-undangan yang ada serta berlaku saat ini.

\section{Pembahasan}

\section{Keabsahan Perjanjian Jual Beli Melalui Sistem Elektronik.}

Dalam kegiatan jual beli melalui sistem elektronik, para pihak akan terlibat dalam suatu perjanjian jual beli. Perjanjian jual beli merupakan suatu perjanjian yang dimana salah satu pihak mengikatkan dirinya untuk menyerahkan sutu barang/benda, dan pihak yang lainnya untuk membayar harga yang telah disepakati. Unsur pokok paling penting yang harus disepakati oleh kedua belah pihak dalam perjanjian jual beli adalah barang dan harga. ${ }^{6}$ Dalam Pasal 1320 KUH Perdata, disebutkan ada 4 (empat) syarat sahnya suatu perjanjian, yaitu:

a. Adanya kesepakatan kehendak oleh kedua belah pihak

Maksud dari kata 'sepakat' itu sendiri adalah kedua belah pihak yang melakukan suatu perjanjian setuju dengan hal-hal pokok yang telah diatur dalam kontrak. Dengan syarat kesepakatan kehendak ini, dimaksudkan agar suatu kontrak yang telah dibuat dapat dikatakan sah di mata hukum. ${ }^{7}$

Kesepakatan dalam transaksi E-commerce terjadi pada saat costumer menekan tombol beli, setelah pembeli mengisi daftar pembelian sebagai Digital Order (DO), sesuai dengan asas konsensualisme dalam hukum perdata, maka transaksi jual beli telah terjadi pada saat terjadinya kata sepakat mengenai harga dalam suatu barang. ${ }^{8}$ Pembayaran dalam transaksi E-commerce dapat dilakukan dengan berbagai cara, antara lain adalah dengan menggunakan kartu kredit, kartu cash (debet), maupun tunai pada saat barang diterima oleh pembeli (cash on deliver). Pembayaran dengan menggunakan kartu kredit adalah merupakan pembayaran mudah, praktis dan banyak dilakukan, karena merupakan pembayaran yang paling mudah, praktis dan cepat. Costumer cukup hanya menentukan barang apa yang dibutuhkan dari webstore atau shopping online dan memasukkan nomor kartu kreditnya. Setelah costumer memasukkan data kartu kreditnya, transaksi costumer langsung diproses. ${ }^{9}$

b. Kecakapan untuk melakukan suatu perbuatan hukum

Yang dimaksud 'cakap' untuk melakukan suatu perbuatan hukum yaitu bagi setiap orang yang sudah dewasa dan sehat pemikirannya. Maksud dari sehat pemikirannya adalah orang yang dapat berfikir secara rasional dan menggunakan akal sehat untuk dapat menimbang-nimbang baik buruknya ataupun untung ruginya. Menurut ketentuan KUHPerdata, yang dimaksudkan dewasa adalah laki-laki dengan usia 21 tahun dan wanita dengan usia 19 tahun. Didalam melakukan perjanjian jual beli barang tersebut, seorang harus cakap terlebih dahulu didalam melakukan perbuatan hukum. ${ }^{10}$

c. Adanya obyek/hal tertentu

Dalam hal ini sesuatu yang diperjanjikan di dalam suatu perjanjian haruslah suatu hal atau barang yang cukup jelas. "Maksudnya adalah, obyeknya harus ada dan harus jelas tidak boleh samar-samar, paling tidak suatu hal atau barang tersebut dapat ditentukan. Hal ini sangat penting sekali untuk memberikan jaminan dan

\footnotetext{
${ }^{6}$ Theresia Thesa Handayani, sebagai pegawai toko di Tokn Elektronik City, Tanggal 25 Juli 2020.

${ }^{7}$ R. Soerusa, Perjanjian Dibawah Tangan, Penerbit Sinar Grafika, Jakarta, 2001, hal. I2

${ }^{8}$ Ustadiyanta, Riyche, Framwork E-commerce, Andi, Yogyakarta, 2001, hal. 56

${ }^{9}$ M. Suyanta, Strategi Periklanan Padsa E-Commerce Perusahaan Top Dunia, Andi, Yogyakarta, 2003, hal. 33.

${ }^{10}$ R. Subekti, Hukum Perjanjian, PT. Intermasa, Jakarta, 1979, hal. 20.

"R. Subekti, Aneka Perjanjian, Cetakan IX, PT. Citra Aditya Bakti, Bandung, I982, hal. 44.
} 
memberikan suatu kepastian kepada pihak pembeli maupun pihak penjual agar tidak adanya pihak yang merasa dirugikan dan/atau menimbulkan kontrak yang batal demi hukum. Didalam melakukan perjanjian jual beli barang elektrik tersebut barang atau benda tersebut harus jelas tidak boleh ada luka atau lecet sedikitpun

d. Adanya kausa yang diperbolehkan/halal

Dalam hal ini maksudnya adalah bahwa suatu perjanjian yang dibuat harus dengan alasan yang sesuai dengan hukum yang berlaku. Jadi, suatu perjanjian tidak boleh untuk dibuat jika isi dalam perjanjian itu bertentangan dengan ketentuan hukum yang belaku di Indonesia, tidak dilarang oleh undang-undang atau tidak bertentangan dengan kesusilaan/ketertiban umum (Pasal 1337 KUH Perdata). Selain itu, jika perjanjian dibuat tanpa sebab yang halal melainkan dibuat karena suatu sebab yang palsu atau terlarang maka perjanjian itu tidak mempunyai ketentuan hukumnya (Pasal 1335 KUH Perdata).

Syarat pertama dan kedua Pasal 1320 KUH Perdata disebut syarat subyektif, karena melekat pada diri orang yang menjadi subyek perjanjian. Jika syarat ini tidak dipenuhi. Perjanjian dapat dibatalkan maksud dari perjanjian dapat dibatalkan artinya salah satu pihak dapat meminta pembatalan itu. Perjanjiannya sendiri tetap mengikat kedua belah pihak, selama tidak dibatalkan (oleh hakim) atas permintaan pihak yang berhak meminta pembatalan tadi (pihak yang tidak cakap atau pihak yang memberikan sepakatnya secara tidak bebas).

\section{Bentuk Perlindungan Hukum Pembeli Atas Kerugian Akibat Rusaknya Barang Yang Dibeli Melalui Sistem Elektronik}

Perlindungan hukum adalah memberikan pengayoman kepada hak azasi manusia yang dirugikan orang lain dan perlindungan tersebut diberikan kepada masyarakat agar mereka dapat menikmati semua hak-hak yang diberikan oleh hukum. Dalam Pasal 1 ayat (1) UndangUndang Nomor 8 Tahun 1999 menyebutkan bahwa Perlindungan Konsumen adalah segala upaya untuk menjamin adanya kepastian hukum untuk memberi perlindungan kepada konsumen. Perlindungan konsumen memiliki cakupan yang sangat luas, meliputi perlindungan konsumen terhadap barang dan jasa, yang berawal dari tahap kegiatan untuk mendapatkan barang dan jasa hingga sampai akibat-akibat dari pemakaian barang dan/atau jasa tersebut. ${ }^{12}$

Bentuk perlindungan hukum dapat dibedakan menjadi dua, yaitu:

a. Perlindungan Hukum Preventif

Perlindungan yang diberikan oleh pemerintah dengan tujuan untuk mencegah sebelum terjadinya pelanggaran. Hal ini terdapat dalam peraturan perundangundangan dengan maksud untuk mencegah suatu pelanggaran serta memberikan rambu-rambu atau batasan-batasan dalam melakukan suatu kewajiban.

b. Perlindungan Hukum Represif

Perlindungan hukum represif merupakan perlindungan akhir berupa sanksi seperti denda, dan hukuman tambahan yang diberikan apabila sudah terjadi sengketa atau telah dilakukan suatu pelanggaran. Dalam Pasal 1 ayat (2) disebutkan pengertian konsumen yaitu dimana setiap orang pemakai, pengguna barang dan atau jasa yang tersedia dimasyarakat untuk kepentingan atau kebutuhan diri sendiri maupun orang banyak. Pemenuhan penggunaan barang dan atau jasa dilakukan oleh pelaku usaha. Pelaku usaha ialah setiap orang atau badan usaha yang berbentuk hukum

\footnotetext{
${ }^{12}$ Undang-undang Nomor 8 Tahun 1990 tentang Perlindungan Konsume, Pasal I Ayat (I)
} 
melakukan kegiatan di wilayah Republik Indonesia menyelenggarakan kegiatan usaha dalam bidang ekonomi. Konsumen/pembeli sebagai pengguna barang atau jasa seringkali mendapati barang yang dibeli dari pelaku usaha rusak, cacat pada barang atau tidak sesuai dengan yang ditampilkan pada gambar yang terdapat pada aplikasi penjual.

Dengan kerusakan barang tersebut menyebutkan konsumen/pembeli merasa dirugikan oleh pelaku usaha/penjual dan sebagai pelaku usaha hendaknya harus lebih memeriksa barang yang diperdagangkan sebelum barang tersebut dikirim kepada pembeli supaya tidak merugikan pembeli. Kerugian yang didapat pembeli akibat tidak bertanggungjawabnya untuk mengganti kerugian yang diderita pembeli atas barang yang dibeli dapat diklasifikasikan dalam:

1. Kerugian materiil

2. Kerugian immateriil

Oleh karena itu gugatan konsumen terhadap produsen yang telah melakukan perbuatan melawan hukum, yaitu menjual produk yang rusak yang menyebabkan timbulnya kerugian bagi pembeli serta adanya unsur kesalahan yang dilakukan pelaku usaha berdasarkan UndangUndang Nomor 8 Tahun 1999 tentang Perlindungan Konsumen karena adanya prindip praduga bersalah dan tanggungjawab produk tidak hanya dalam UUPK tetapi KUH Perdata juga memberikan perlindungan kepada pembeli yang menderita kerugian akibat rusaknya barang yang dibeli. Dalam hal terdapat kerusakan baik cacat tersembunyi, pembeli dapat memilih beberapa opsi sebagaimana diatur dalam Pasal 1507 KUH Perdata antara lain:

1. Penguasaan barang yang dijual itu secara aman dan tenteram

2. Tiadanya cacat yang tersembunyi pada barang tersebut atau yang sedemikian rupa sehingga menimbulkan alasan untuk pembatalan pembelian.

Dalam hal-hal terdapat cacat tersembunyi, konsumen dapat memilih beberapa opsi sebagaimana diatur dalam Pasal 1507 KUH Perdata antara lain:

1. Mengembalikan barangnya sambil menuntu kembali uang harga pembelian; atau

2. Akan tetapi memiliki barang itu sambil menuntut kembali sebagian dari uang harga pembelian sebagaimana ditentukan oleh hakim setelah mendengar ahli-ahli tentang itu.

Adapun dari sisi penjual dalam kaitannya dengan cacat tersembunyi, terdapat dua kewajiban yang harus dilakukan:

1. Jika penjual telah mengetahui terdapat cacat pada barang tersebut, maka penjual wajib mengembalikan uang harga pembelian yang telah diterimanya dan mengganti segala biaya, kerugian, dan bunga.

2. Jika penjual tidak mengetahui adanya cacat dalam barang tersebut, maka penjual wajib mengembalikan uang harga barang pembelian dan mengganti biaya untuk menyelenggarakan pembelian dan penyerahan sekedar itu dibayar oleh pembeli. ${ }^{13}$

Berdasarkan ketentuan Pasal 19 Undang-Undang Perlindungan Konsumen diatur pula mengenai tanggungjawab pelaku usaha didalam menjalankan usahanya yaitu:

1. Pelaku usaha bertanggungjawab memberikan ganti rugi atas kerusakan, pencemaran, dan/atau kerugian konsumen akibat mengkonsumsi barang dan/atau jasa yang dihasilkan atau diperdagangkan.

2. Ganti rugi sebagaimana dimaksud dalam ayat (1) dapat berupa pengembalian uang atau penggantian barang dan/atau jasa yang sejenis atau serta nilainya, atau perawatan kesehatan dan/atau pemberian santunan yang sesuai dengan ketentuan peraturan perundang-undangan yang berlaku.

\footnotetext{
${ }^{13}$ R. Subekti, Aneka Perjanjian, PT. Citra Aditya Bakti, Bandung, 1995, hal. 20
} 
3. Pemberian ganti rugi dilaksanakan dalam tenggang waktu 7 (tujuh) hari setelah tanggal transaksi.

Dalam Bab VIII Pasal 38 Undang-Undang No. 11 Tahun 2008 tentang Informasi dan Transaksi Elektronika ada memuat penyelesaian sengketa konsumen yaitu:

1. Setiap orang dapat mengajukan gugatan terhadap pihak yang menyelenggarakan sistem elektronik dan/atau menggunakan teknologi informasi yang menimbulkan kerugian.

2. Masyarakat dapat mengajukan gugatan secara perwakilan terhadap pihak yang menyelenggarakan sistem elektronik dan/atau menggunakan teknologi informasi yang berakibat merugikan masyarakat, sesuai dengan ketentuan peraturan perundang-undangan.

Pasal 39 undang-undang No. 11 Tahun 2008 tentang Informasi dan Transaksi Elektronik lanjutan dari Pasal 38 mengenai penyelesaian sengketa konsumen yaitu:

1. Gugatan perdata dilakukan sesuai dengan ketentuan peraturan perundangundangan.

2. Selain penyelesaian gugatan perdata sebagaimana dimaksud pada ayat (1), para pihak dapat menyelesaiakn sengketa melalui arbitrase, atau lembaga penyelesaian sengketa alternatif lainnya sesuai dengan ketentuan peraturan perundangundangan.

Penyelesaian sengketa konsumen ini diatur dalam Pasal 45 Undang-Undang No. 8 Tahun 1999 yang berbunyi:

1. Setiap konsumen yang dirugikan dapat menggugat pelaku usaha melalui lembaga yang bertugas menyelesaikan sengketa antara konsumen dengan pelaku usaha atau melalui peradilan yang berada di lingkungan Peradilan Umum.

2. Penyelesaian sengketa konsumen dapat ditempuh melalui pengadilan atau di luar pengadilan berdasarkan pilihan sukarela para pihak yang bersengketa.

3. Penyelesaian sengketa di luar pengadilan sebagaimana dimaksudkan pada ayat (2) tidak menghilangkan tanggungjawab pidana sebagaimana diatur dalam UndangUndang.

4. Apabila telah dipilih upaya penyelesaian sengketa konsumen di luar pengadilan, gugatan melalui pengadilan hanya dapat ditempuh apabila upaya tersebut dinyatakan tidak berhasil oleh salah satu pihak atau oleh para pihak yang bersengketa.

Oleh karena itu perbuatan melawan hukum yang timbul dalam transaksi jual beli secara elektronik/melalui internet dapat diselesaikan baik secara litigasi ataupun secara non litigasi, sesuai kesepakatan para pihak, sehingga tidak ada kekosongan hukum yang dapat berakibat menimbulkan kerugian yang lebih besar lagi.

\section{D.Kesimpulan}

Adapun yang menjadi kesimpulan dalam penelitian ini adalah :

1. Bahwa keabsahan perjanjian jual beli melalui sistem elektronik yaitu tetap melihat kepada syarat-syarat yang diatur didalam Pasal 1320 KUH Perdata yang menentukan bahwa syarat sahnya suatu perjanjian adalah sebagai berikut:
a. Kesepakatan para pihak
b. Kecakapan untuk membuat perjanjian
c. Suatu hal tertentu
d. Suatu sebab yang halal 
Empat syarat di atas masih dapat dibagi lagi menjadi dua unsur yaitu unsur subyektif dan unsur obyektif. Dalam hal tidak dipenuhi unsur subyektif (syarat kesepakatan dan kecakapan) maka perjanjian tersebut dapat dibatalkan. Sedangkan apabila unsur obyektif (suatu hal tertentu dan suatu sebab yang halal) tidak dipenuhi maka perjanjian tersebut berakibat batal demi hukum.

2. Bentuk perlindungan hukum pembeli atas kerugian akibat rusaknya barang yang dibeli melalui sistem elektronik, yaitu:

a. Perlindungan hukum preventif dan represif;

b. Pasal 1507 KUH Perdata menentukan dalam hal terdapat rusak, cacat tersembunyi, pembeli/konsumen dapat memilih beberapa opsi antara lain: mengembalikan barangnya sambil menuntut kembali uang harga barang pembelian atau akan tetap memiliki barang itu sambil menuntut kembali sebagian dari uang harga pembelian sebagaimana ditentukan olah hakim.

c. Pasal 38 dan Pasal 39 Undang-Undang No. 11 Tahun 2008 tentang Informasi dan Transaksi Elektronik yaitu setiap orang dapat mengajukan gugatan terhadap pihak yang menyelenggarakan sistem elektronik dan/atau menggunakan teknologi informasi yang menimbulkan kerugian.

d. Pasal 45 Undang-Undang No. 8 Tahun 1999 tentang Perlindungan Konsumen yaitu setiap konsumen yang dirugikan dapat menggugat pelaku usaha melalui lembaga yang bertugas menyelenggarakan sengketa antara konsumen dengan pelaku usaha atau melalui peradilan yang berada di lingkungan peradilan umum.

\section{Daftar Pustaka}

Djoko Prakoso dan Bambang Riyadi lany, Dasar Hukum Persetujuan Tertentu di Indonesia, Bina Aksara, Jakarta, 1987.

M. Suyanto, Strategi Periklanan Padsa E-Commerce Perusahaan Top Dunia, Andi, Yogyakarta, 2003.

Peter Mahmud Marzuki, Penelitian Hukum, Cetakan keenam, Kencana Prenada Media Grup, Jakarta, 2010.

R. Soeroso, Perjanjian Dibawah Tangan, Penerbit Sinar Grafika, Jakarta, 2001.

R. Subekti, Hukum Perjanjian, PT. Intermasa, Jakarta, 1979. Aneka Perjanjian, Cetakan IX, PT. Citra Aditya Bakti, Bandung, 1982. Aneka Perjanjian, PT. Alumni, Bandung, 1992. Aneka Perjanjian, PT. Citra Aditya Bakti, Bandung, 1995.

Theresia Thesa Handayani, sebagai pegawai toko di Toko Elektronik City, Tanggal 25 Juli 2020. Ustadiyanto, Riyche, Framwork E-commerce, Andi, Yogyakarta, 2001.

\section{Peraturan Perundang-undangan}

Kitab Undang-Undang Hukum Perdata.

Undang-Undang Nomor 8 Tahun 1999 tentang Perlindungan Konsumen. Undang-Undang Nomor 19 Tahun 2016 tentang Informasi dan Transaksi Elektronik. 